\title{
赤外分光測光における走査歪みの解析
}

\author{
南 茂 夫*。筒 井 滋* \\ （昭和 43 年 8 月 10 日受理）
}

\section{Analysis of Tracking Error in Infrared Recording Spectrophotometry}

\author{
Shigeo MINAMI and Shigeru TSUTSUI \\ Department of Applied Physics, Faculty of Engineering, Osaka University \\ (Higashinoda 9, Miyakojima, Osaka)
}

The tracking error caused by the dynamic characteristics of recording spectrophotometers is discussed and analyzed. Under the limited signal-to-noise ratio and available measuring time, the distortion of bands in the recorded spectrum due to the insufficiency of the response of the recording system introduces an appreciable error. The analysis is carried out by computing the distortions for Gaussian and Lorentzian bands by means of an analog simulator after having derived the transfer functions of the recording spectrophotometers. Prior to demonstrating the process of this procedure, the detailed steps in simplifying the block diagrams of the systems are illustrated. The analysis of the tracking errors is carefully done taking into consideration that the signal-to-noise ratio is dominated by the detector noise. The computed values of the tracking errors are in good agreement with the experimental ones obtained with commercial instruments. This procedure of the analysis might be helpful not only to the determination of the parameters in instrument designing but to find the optimum condition of the measuring programs in the recording spectrophotometry.

\section{1. 緒言}

自記分光測光においてその測光性能の評洒には，単な る測光精度だけでなく測光に要する時間も含めて考光な ければならない，換言すれば測光系を一種の情報処理系 とタなして評価し宗ければならないことであり，特に長 波長領域の赤外分光測光に扮いて，利用出来方有效工ネ ルギの低下，検知器の感度不足等から測光長時間定要 することを考光机活，きわめて妥当な評価法と言光よ う。このような評価基準に從うるのとす机ば, 自記分光 測系の構成飞当たつて注有效な情報を最大限に利用する ように諸要素を合理的に結合しなければならないととが 必然的に要求される。それ机選択すべき系の design parameter や動作条件を, 測光精度との関連において 西らかじめ明確にしておく必要がある。筆者らはこのよ うな見地に立台, 所要の解析をシミュレーションの手法 で実行するため, 各種分光測光系の信号伝達状態を摸擬

* 大阪大学工学部灾用物理学教室 (大阪市都島区東野 田 9 丁目。
できるアナログシミュレータを試作し，装置の詳細敊よ びシミュレーションの実例について既に報告した1).

自記分光測光において現われる主な測光誤差はたと元 迷光・高次光除去が完全であり，工作精度などに由来す る機械系自体の誤差が無視しうるとしても，光学的装置 関数(スリット関数)で左右されるスペクトルの歪久, 増 幅記録系の応答が有限であることにもとづく走查歪久， ならびに主として検出器から生ずる不規則椎音にもとづ くものが考光られる。これらのうち前二者は系統的誤差 であるから，系の動作条件や design parameter などと 関連して解析することが出来るものである．特に光学的 装置関数で表わされるスペクトルの歪みに関しては， 過去に拈いてとの補正法も含めて詳しく解析されてい る2,3)。また不規則雑音による誤差に関しては，上述の

1）筒井 滋, 南 茂夫, 藤田 茂, 分光研究 16, 78 (1967).

2) K.S. Seshadri, R.N. Jones: Spectrochim. Acta 19, 1013 (1963).

3) A.F. Jones, D.L. Misell: Brit. J. Appl. Phys. 18, 1479 (1967). 
ような配慮が特に要求される赤外域の自記分光測光系で は光束断続法を採用するのが常識であり，搬送波近傍で は雑音のパワスペクトルは注淁平坦と考えら礼るので， 後に示されるようにこの種の誤差は比較的容易に近似評 価できる.

一方走查歪多に関して注従来から解析倍易な一次系 あるいは臨界制動型二次系のフィルタ定対像とした場合 が多く4,5)，また Stewart ${ }^{6)}$ は上記以外の種々の伝達関 数をも解析の対像としているが，いずれも伝達関数とこ れに対応する系の信号伝達状態あるいは装置の実際的構 成内容との関係が明確にされていない。主た走査歪みを 単にピーク值の誤差のみとしたり，場合によつて line shift のみなど単一のパラメータのみに注目している場 合が多く，走査歪みの評価法に関しても充分とは言えな い.

筆者らはこのような点老考慮し走查歪みの解析汇先立 ち，系の信号伝達状態穵ブロック図で記述し，これにも とづき系の伝達関数学導くことにより, 実際の装置との 関連を明らかにした。走查歪みは Ramsey 法2)と同じく 真のスペクトルに対する記録スペクトルのピーク值掞よ び半值幅の誤差ならびに line shift で評洒し, さらに真 のスペクトルの形状として Gauss 形およびLorentz 形 の単一波形と仮定したが，これらの妥当性をも同時に検 討した．解析は試作したアナログシミニレータにより実 時間で行なわれるので, 系の特性, 入力波形の設定等は きわわて簡単となることはもちろんで㐫る。

解析結果から自記分光測光に叔的最適系の設計につ いての条件和よび既製の装置を使用する上での測定条件
設定の基準が明らかになつたが，さらに各種の系につい てその周波数特性を検討することによつて，この取扱い の妥当性を確認した。また市販されている自記分光測光 装置を使用して実際のスペクトルの走査歪多実測し， 筆者らの解析法が実用上充分満足しうることを認めた。

\section{2. 自記分光測光系の伝達関数による表示}

走查雨みの解析を実行するためには自記分光測光系の 伝達関数を導かなければならないが, 以下では各種の自 記分光測光系をそれらの信号伝達状態の相違に着目して 次の二方式に分類して検討を進める.すなわ方单光束直 接記録方式で代表される開ループ系方式と複光束光学的 零位方式の閉ループ系方式について考察するものとして Fig. 1 小よび 2 にとれぞれの方式をブロック図で表示 してある.ここで系注すべて線形要素で構成されると考 光且つ搬送波交流系を直流系で近似している. 字た検知 器および増愊器の周波数特性は, 信号の占有周波数帯域 内で定数とみなしそれらの伝達関数定それぞれ $K_{d}, K_{a}$ で示してある.さらに同期整流回路後部に配置されるフ ィルタは通常は R.C 素子で構成されており， $T_{f}, T_{f_{1}}$, $T_{f_{2}}$ 注実数と考光ることができる.さらにこのフィルタ により同期整流回路出力のうち, いかゆるリップルとな つて現われる一次以上の高調波は無視し得る程度に小さ くなるものと考える. 以上の仮定は一般の自記分光測光 系で充分に成り立つ事柄である。 また検知器自体から発 生する不規則雑音は検知器後部に加わる外乱とみなす とが出来るので，それぞれ図に示されるようにこの雑音 のパワスペクトル $N(\omega)$ で表示してある.

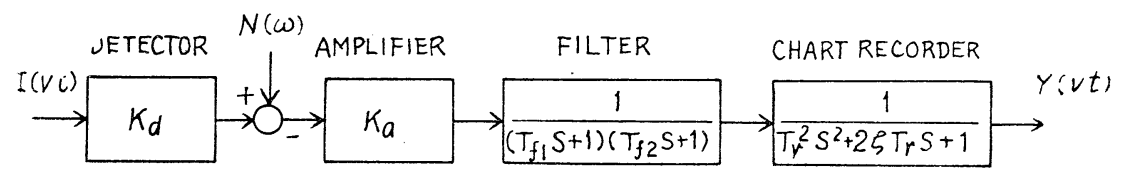

(a)

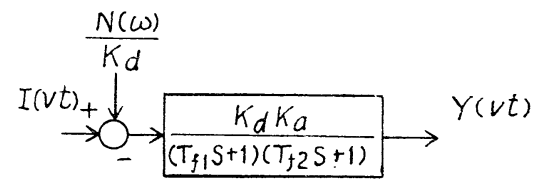

(b)

Fig. 1. Functional block diagram of single-beam spectrometer (a) and its representation by a single block (b).

4) S. Brodersen: J. Opt. Soc. Am. 43, 1216 (1953).

5) G. Schreiber: Z. angew. Phys. 18, 221 (1964).

6) J.E. Stewart: Infrared Phys. 7, 77 (1967).
Fig. $1(a)$ に尔いて $I(V t)$ および $I_{0}(V t)$ はそれぞれ測

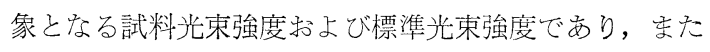
$Y(V t)$ 注記録波形である. いずれも本来は波数的関数 


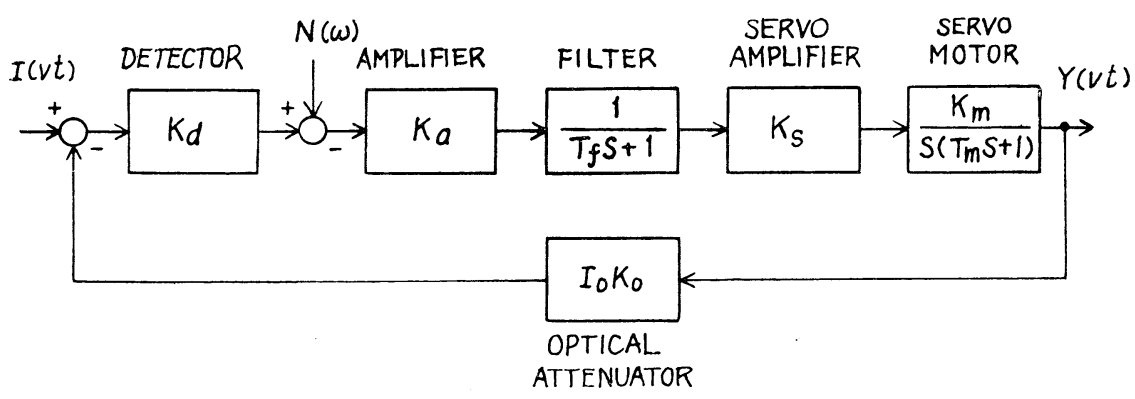

(a)

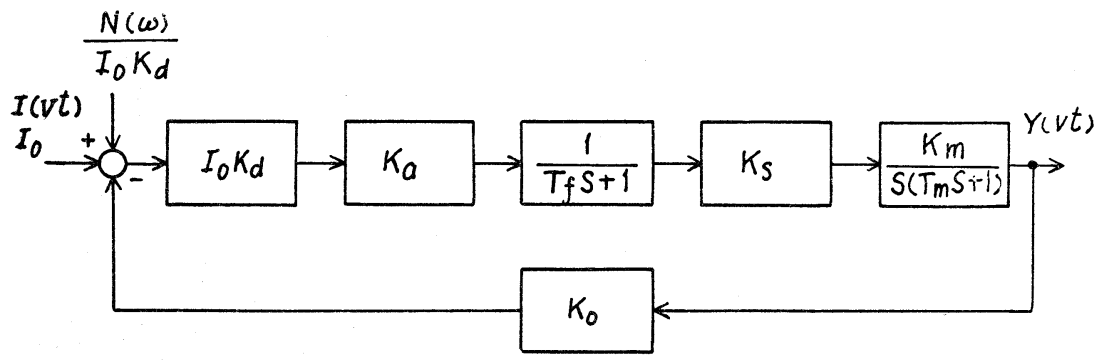

(b)

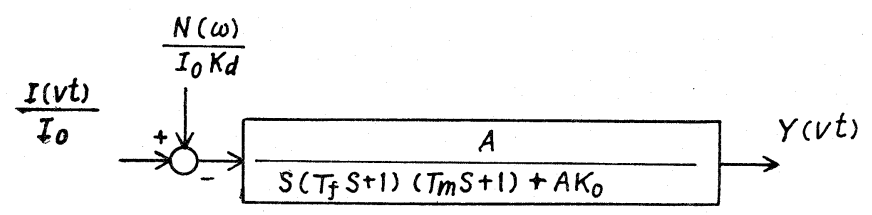

$A=I_{0} K_{d} K_{a} K_{s} K_{m}$

(C)

Fig. 2. Functional block diagram of optical null double-beam spectrophotometer and steps in the reduction of the diagram to an equivalent single block.

であるが波数走查速度 $V\left(\mathrm{~cm}^{-1} / \mathrm{sec}\right)$ 定介して時間関数 として示してある. Fig. 1 (b) は Fig. 1 (a)のブロック 図に対してブロック変換をほどこして簡単化したもので あるが，フィルターの周波数帯域幅は記録用チャートレ コーダのそれに比較して充分に狭く設計されるので, 走 查歪夕に関してはこのチャートレコーダの伝達関数注ほ とえど関与しないことになり, Fig. 1 (b) では省略して

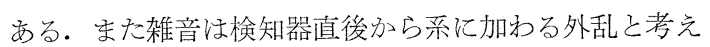
られるが, Fig. 1 (b) では等価的に検知器に入射する 光束の不規則变動に変換してある. この結果から開ルー プ系方式の伝達関数は実質的にはフィルタの伝達関数す なわち一般には一次系あるいは二次系で近似されること になる。

Fig. 2 (a) の閉ループ系方式で注測定の対象は強度比 $I(\boldsymbol{\nu}) / I_{0}(\boldsymbol{\nu})$ であり， $Y(\boldsymbol{\nu})$ はその記録波形である. $I_{0}(\boldsymbol{\nu})$
は後に述べるように一定と考えることができるので, Fig. 2 (a) 洋前記の場合々同様の手法によつてブロック 変換を流どこして Fig. 2 (b) のように書き替えら秃, さらにこれは Fig. 2（c）のように簡単化されることに なる、また雑音に対する取り扱いも同じく系に入射する 光束の不規則変動とみなすととができる．この結果から 閉ループ系方式の伝達関数は少なくとも三次以上の系と なるととが明らかとなるが，一巡伝達関数が三次以上の フィートバック系では条件によつて発振を起こす可能性 があり，一般に閉ループ系方式でも二次系に近似出来る 状態で使用される。これはサーボモータにタコゼネレー 夕を用いたフィードバック回路定付加することによつて 等価的に $T_{m}$ の值を大きくできること，あるい滴当な 回路定数を選択して $T_{f}$ の值を大きくするなど， $T_{f}$ 两 るいは $T_{m}$ の一方が結果として省略出来る状態に系を設 
154

定出来るからである.さらに閉ループ系方式の特徵は Fig. 2 からも明らかなように，その伝達関数に $I_{0}$ も関 与していることである.したがつて $I_{0}$ が変化すれば系 の応答も变化し，いわゆる線形可変係数系として取扱わ なければならないが，一般に複光束の分光光度計では $I_{0}$ をほぼ一定に保つ機構を含さことが多く，また波形歪み を取り扱う場合には，狭い波数域を対象とするので以下 の議論では $I_{0}$ が一定, すなわち線形定数係数系として 取り扱う.

上記の考察にもとづき自記分光測光系は系の信号伝達 状態あるい構成内容にふれることなく一般に Fig. 3 に示されるように考えるものとする．ここで $G(s)$ につ いては系の伝達関数が二次系で近似される場合には

$$
G(s)=\frac{1}{\tau s+1}
$$

となる、ただしては系の時定数である。また二次系で近 似される場合には

$$
G(s)=\frac{1}{T^{2} S^{2}+2 \zeta T S+1}
$$

と置き，らは系の減衰係数， $T$ 注固有周期を表わす。 れらの定数と系の構成要素個々の特性を表わす定数との 関係は Fig. 1，2 索参考として簡単に決めることができ る.また雑音 $N_{1}(\omega)$ はもちろえ $N(\omega) / K d$ あるいは $N(\omega) / I_{0} K d$ を表わすものとする. この場合系の入力信 号 $X(\boldsymbol{\nu})$ は開ループ系方式では $I(\boldsymbol{\nu})$ または $I_{0}(\boldsymbol{\nu})$ で あり，閉ループ系方式では $I(\nu) / I_{0}(\boldsymbol{\nu})$ であるなどの相 違もあるが，ここで怯の内容にふれずに一様に $X(\nu)$ と表少すものとすれば，記録波形 $Y(\boldsymbol{\nu})$ は $X(\boldsymbol{\nu})$ に杂隹 音が重畳したデー夕が伝達関数 $G(s)$ を通過した出力と 考えること妿できる。ここで記録波形 $Y(\nu)$ はもちろえ $X(\boldsymbol{\nu})$ そのものが望ましいから，自記分光測光系は $X(\boldsymbol{\nu})$ 拉よび雑音すなわち雑音を含芑データから必要な情報 $X(\boldsymbol{\nu})$ を抽出するフィルターと考光てよい.

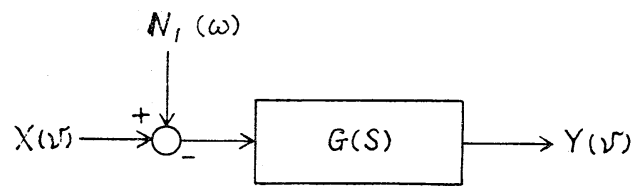

Fig. 3. Input and output relation of a spectrophotometric system.

さて Fig. 3 において, 系は線形であるから，パワス ペクトル密度 $N_{1}(\omega)$ の雑音にもとづく出力のパワ $\sigma_{0}{ }^{2}$ は

$$
\sigma_{0}^{2}=\frac{1}{2 \pi} \int_{0}^{\infty} N_{1}(\omega)|G(j \omega)|^{2} d w
$$

となる.すでに述べたように雑音 $N(\omega)$ 注パワスペク トルがほぼ一定と見なしうるので, $N_{1}(\omega)$ も同じ性質 となり

$$
N_{1}(\omega)=\mathrm{const}=P
$$

と置くことができ，(2.3) 式注次式のように書替えられ る。

$$
\sigma_{0}^{2}=\frac{P}{2 \pi} \int_{0}^{\infty}|G(J \omega)|^{2} d w=P \Delta f|G(j \omega)|^{2}{ }_{\omega=0}
$$

ただし

$$
\Delta f=\frac{1}{2 \pi} \int_{0}^{\infty} \frac{|G(j \omega)|^{2}}{|G(j \omega)|^{2}{ }_{\omega=0}} d w(H Z)
$$

であつて， $\Delta f$ は系の等価雑音帯域幅と称せられるもの である、したがつて，(2.6) 式の定義にもとづき（2.1） 式で表わされる一次系の等価雑音帯域幅 $\Delta f$ は

$$
\Delta f=\frac{1}{4 \tau}
$$

となりまた (2.2) 式で表わされる二次系については

$$
\Delta f=\frac{1}{8 \zeta \bar{T}}
$$

となることが簡単な計算によつて得らるる。なた一般に $|G(0)|^{2}=1$ となるから，(2.5) 式は

$$
\sigma_{0}^{2}=P \Delta f
$$

となり, 検知器雑音のパワスペクトルが明らかであれ ば，(2.9）式の関係にもとづいて雑音による誤差簡単 に評価されることになる。

\section{3. 吸収スペクトルの形状に関する検討}

走査歪みの解析に必要とされる自記分光測光系の伝達 関数は前記の結果により一般には一次系あるい汪二次系 と考えることができるので，この特性をアナログシミュ レータに設定することはきわめて簡単でありシミュレー ションの実施に当たり特に問題は生じない。乙かしなが ら走査歪みの解析には系の特性と共に入力信号波形すな わちこの場合吸收スペクトルの形状が重要であるので,

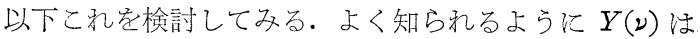
光学的装置関数 $O(\boldsymbol{\nu})$ 崩よび記録系装置関数 $g(\boldsymbol{\nu})$ と真 のスペクトル $X(\nu)$ の convolution 積分で与えられ, 次 式で表わされる。

$$
Y(\boldsymbol{\nu})=g(\boldsymbol{\nu}) \nVdash O(\boldsymbol{\nu}) \nVdash X(\boldsymbol{\nu})
$$

ただし $g(\boldsymbol{\nu})$ は系のインパルス応答を波数の関数として 表わしたもので, すでに求めた伝達関数 $G(\nu)$ と次の関 係がある。 


$$
\int_{0}^{\infty} g(V t) e^{-s t} d t=G(s)
$$

したがつて走査歪みの解析において, 系への入力波形と して設定すべき形状は $O(\boldsymbol{\nu}) * X(\boldsymbol{\nu})$ であり，仮に $X(\boldsymbol{\nu})$ の形状を固定するものとしても $O(\nu)$ の形状によって入 力波形の形状が変わり一層複雑な問題となる.そこで以 下においては議論を簡単にするために光学的装置関数に もとづく歪みが充分に無視できる場合，すなわち $O(\boldsymbol{\nu})$ が一応 $\delta$ 関数に近似できる場合を対象とするものとす る.したがつて (3.1) 式は

$$
Y(\nu)=g(\nu) * X(\nu)
$$

と考えられることになる。

このように仮定するとしても筆者らの解析の対象が吸 収スペクトルの場合であるから， $I(\nu)$ 㐨よび $I_{0}(\nu)$ と 光学濃度 $D(\nu)$ (通常は透過率の逆数の常用対数值を用 いる場合が多いが，ここでは自然対数值で定義する）と の関係は

$$
\log _{e} \frac{I_{0}(\nu)}{I(\nu)}=D(\nu)
$$

であり，一般の分光光度計の測光系では透過率

$$
\frac{I(\nu)}{I_{0}(\nu)}=f(\nu) e^{-D(\nu)}
$$

が測定される点を考慮しなければならないこの $D(\nu)$ は一般に Voigt 形とすべきであるが，簡単のため Gauss 形あるいは Lorentz 形と仮定するものとしても系への 大力信号の形状は一般に (3.5) 式の $f(\nu)$ で与えられる 形となり当然のことながら $D(\boldsymbol{\nu})$ すなわち, Gauss 形 あるいは Lorentz 形とも異なるはずである. 以下にお いてこの差異を検討するが，守ず $D(\nu)$ が Lorentz 形 と仮定するものとして

$$
D(\nu)=\frac{B}{A\left(\nu-\nu_{0}\right)^{2}+1}
$$

とおく.ただし $\nu_{0}\left(\mathrm{~cm}^{-1}\right)$ は吸収帯の中心波数， $B$ はこ の波数に括ける optical density となり，なた $A$ は吸 収带の半值幅を決める定数である. (3.6) 式において

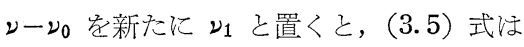

$$
f_{L}\left(\nu_{1}\right)=\exp \left(-\frac{B}{A \nu_{1}^{2}+1}\right)
$$

の形となる・この関数の peak 值は $e^{-B}$ であり,また 半值幅を $2 W$ とすれば

$$
A W^{2}+1=\frac{-B}{\log _{e} \frac{1}{2}\left(1-e^{-B}\right)}
$$

の関係がある。同様に $D(\nu)$ が Gauss 形と仮定できる
時には，前述の場合と同じ定数を用いて

$$
D(\boldsymbol{\nu})=B \cdot \exp \left\{-A\left(\boldsymbol{\nu}-\boldsymbol{\nu}_{0}\right)^{2}\right\}
$$

と表わされ，したがつて

$$
f_{G}\left(\nu_{1}\right)=\exp \left\{-B \exp \left(-A \nu_{1}^{2}\right)\right\}
$$

となる。この場合も吸収带の peak 值は $e^{-B}$ であり, 半值幅 $2 W$ と $A$ の関係は

$$
A W^{2}=-\log _{e}\left\{\frac{-\log _{e} \frac{1}{2}\left(1+e^{-B}\right)}{B}\right\}
$$

となる。

ここで波数レ它 $W$ で規格化して新たに

$$
u=\frac{\nu_{1}}{W}
$$

とすれば

$$
\begin{aligned}
& f_{L}(u)=\exp \left(\frac{-B}{A W^{2} u^{2}+1}\right) \\
& f_{G}(u)=\exp \left\{-B \exp \left(-A W^{2} u^{2}\right)\right\}
\end{aligned}
$$

となり，これらは (3.8)，(3.11）式により $A W^{2}$ を消

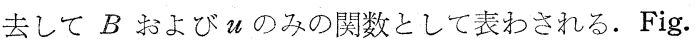
4 はこの結果であるぶ，比較を容易にするためピーク值 を1に規格化盯るため $\left\{1-f(u) e^{B}\right\}$ の形に变換して画い てある。

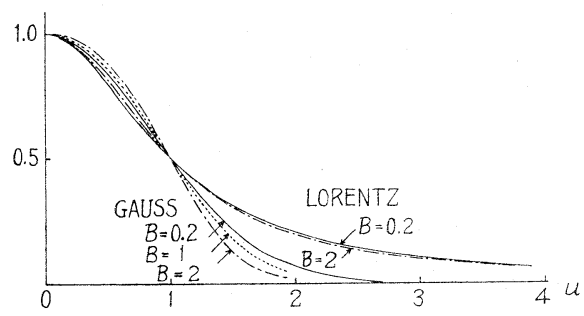

Fig. 4. Plot of $\left\{1-f(u) e^{B}\right\}$ as a function of $u$ for various $B^{\prime} s$.

Fig. 4 において $B$ が 0.2 すなお吸收带ピークの 透過率が $81.9 \%$ で表わされる浅い吸収の場合には，そ れぞれ真の Gauss 形あるいは Lorentz 形波形と最大 $0.5 \%$ の差以内で一致している. $D(\nu)$ 唯 Lorentz 形の 場合には $B$ が 2 すなから吸收ピークが透過率 $13.5 \%$ で 表わされるときでも最大 $1.5 \%$ 差以内で真の Lorentz 形, 波形飞一致している. 一方 $D(\boldsymbol{\nu})$ 出 Gauss 形の場 合には Lorentz 形の場合注ど一致は良くないが， $B$ が 1 すなわら吸収ピークの透過率が $36.0 \%$ となる時, 吸収 の裾部分を除けば $1 \%$ 以内の差で真の Gauss 形波形々一 致している.一般にBの值が増大し，吸収が深くなるほ 
ぞスペクトルの形状淔の Gauss 形あるいは Lorentz 形から隔たることが明らかである。一方 Brodersen ${ }^{7}$ に よれば静的な分光測光に抢いても透過率が $20 \%$ 以下と なれば雑音による光学濃度の測定誤差が急激仁增大する ことが示されて和り, 実用上吸収スペクトルも Gauss 形 あるいは Lorentz 形関数とみなせる範囲で分光測光が 実施されるものと考光ることができる。

\section{4. 走査歪みの解析結果ならびに最適系の決定}

(3.3) 式に抒いて $g(\boldsymbol{\nu})$ 另 $\delta$ 関数でないかぎり $Y(\boldsymbol{\nu})$ 之 $X(\boldsymbol{\nu})$ 注異なり, その差異が走查歪みであるが, 記録 系沈括る誤差はこの歪みに (2.9) 式で与えられる不規 則䧴音による誤差が重畳したものである。しかしながら 系法線形々考えているから走査歪久だけを独立に評洒し うる.この評価はつまるところ $Y(\nu)$ と $X(\nu)$ の比較で 西つて, 一般に二種の波形の比較は二乗誤差面積等を判 定基準にすることが多いが，対象をスペクトルに限る と, ピーク值と半值幅の变化量で評価される場合が多 く，筆者らもこの方法它採用するすのとする.ここで比 較の基準となる波形はもちろ几測定すべきスベペクトル $X(\boldsymbol{N})$ で Gauss 形波形であれば

$$
X(\nu)=P \exp \left(-\frac{\nu^{2} \log _{e} 2}{W^{2}}\right)
$$

とし, Lorentz 形波形であ机ば

$$
X(\nu)=P \frac{W^{2}}{\nu^{2}+W^{2}}
$$

で表わすととにする。いずれの波形もピーク值に $P$, 半 值幅は $2 W$ として西る. したがつて Fig. 5 に示され るよう記録波形 $Y(\boldsymbol{\nu})$ のピーク值および半值幅が， $P^{\prime}, 2 W^{\prime}$ であるものとすればとれぞれの誤差は $\Delta P=$ $P-P^{\prime} 2 \Delta W=2\left(W-W^{\prime}\right)$ で, また line shift $\Delta \Delta$ で 走査歪みが評価される。

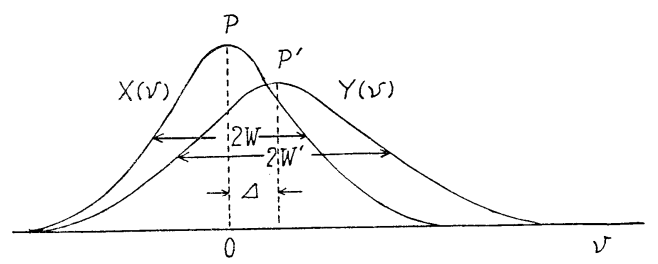

Fig. 5. True and distorted band shapes.

Fig. 6 (a), (b), (c) अ $X(\nu)$ として Gauss 形波形 をとり, 系の特性活一次系抢よび種々の減衰俰数の二次 系としたときの走査歪みをアナログシミュレーションの 手法で解析した結果を⿱上小たものである。それぞれピ

7) S. Brodersen: J. Opt. Soc. Am. 43, 877 (1953)
ーク值の誤差 $\Delta P / P(\%)$, 半值幅の誤差 $\Delta W / W(\%)$ および line shift $A / W$ を $1 / K$ の関数で画いてある. ただし $K$ は

$$
K=\frac{8 W \Delta f}{V}
$$

で定義さ机る量で, 記録系の動作条件を定めるパラメー タである. Fig. 7 は $X(\nu)$ として Lorentz 形波形を とつたときの同様の解析結果である.いずれの場合も解 析結果の精度はピーク値および半值幅の誤差に関しては $\pm 0.3 \%$ および line shift に関しては \pm 0.02 である. 系のパラメータ $1 / K$ 注 (2.9), (4.3) 式から明らかな ように走査速度に比例し， $\Delta f$ すなわ台記録される雑音 パワに反比例するので，この值ができるだけ大きな状態 で自記分光測光が実行し得ることが望なしい. Fig. 6,7 の結果から $X(\nu)$ の形状が Gauss 形あるい注 Lorentz 形のいずれであつても, 系を減衰系数が 0.8 の二次系に 設定すれば広い範囲でピーク値およで半值幅の䛊差が最 も少ないととが明らかであり，最適な系であるものとい える、また line shift はた党ば一次系のそ礼よりも大 きくなるが, 反面この系で注ほぼ $1 / K$ すなわ方走速 度に比例する範囲が広くなり，この意味でも優れている ことになる。もちろえ最適な系は分光測光の要求によつ て当然異なる注ずで，たとえばスペクトルがLorentz 形

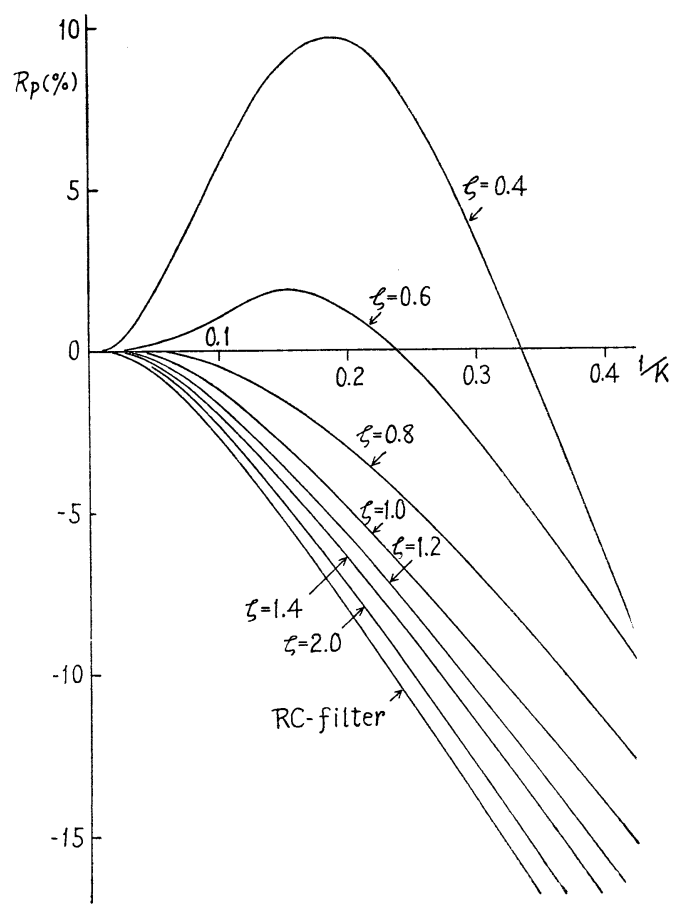

Fig. 6, (a) 


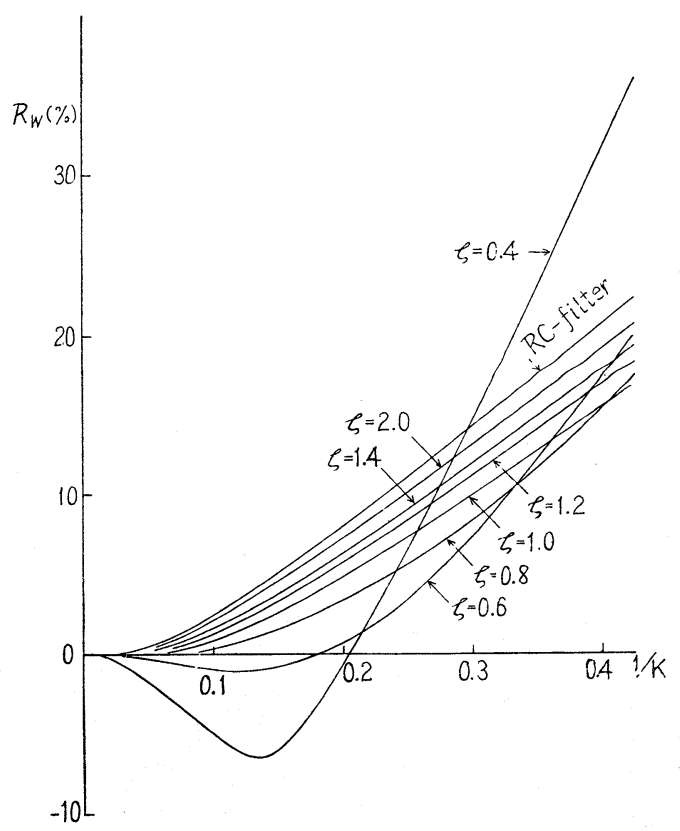

Fig. 6, (b )

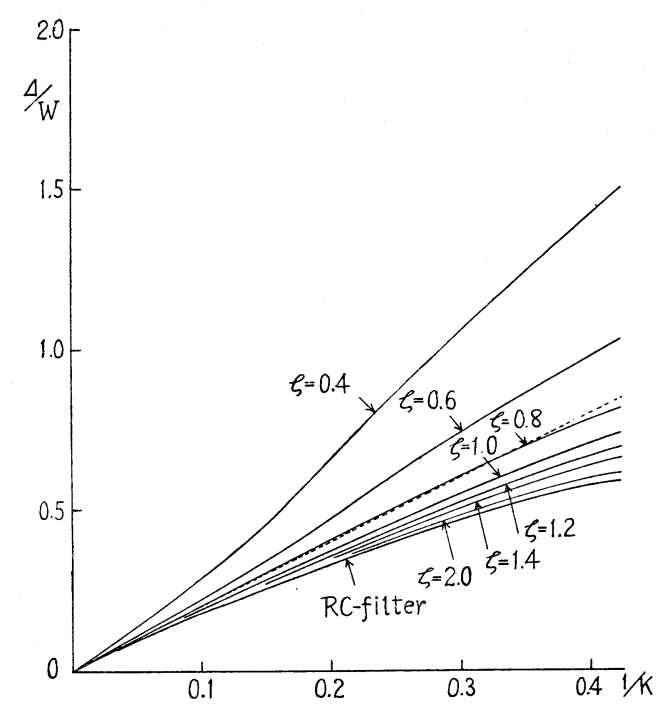

Fig. 6, (c)

Fig. 6. Tracking errors for a Gaussian band in various system responses. (a) peak height errors, (b) half-width errors and (c) line shifts.

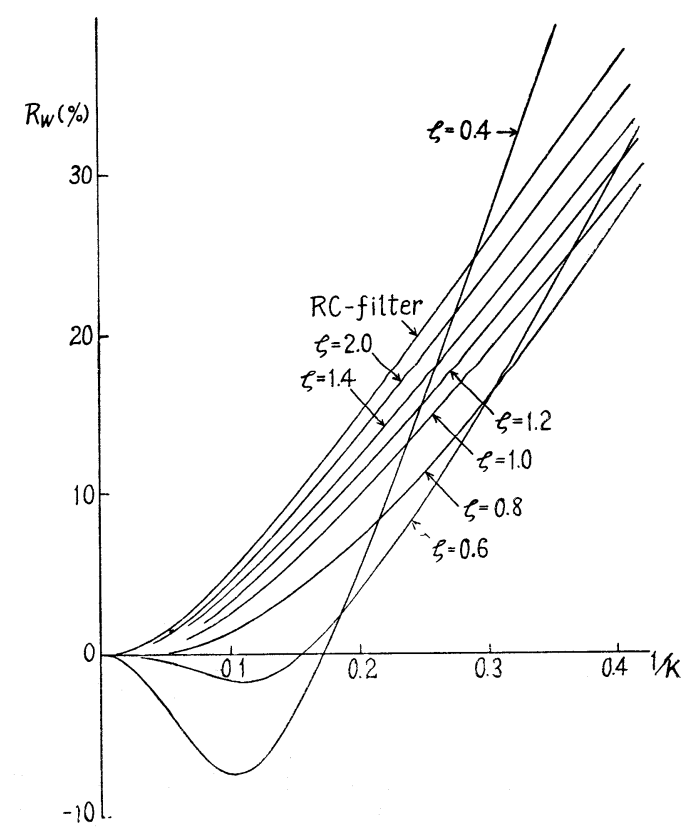

Fig. 7, (a)

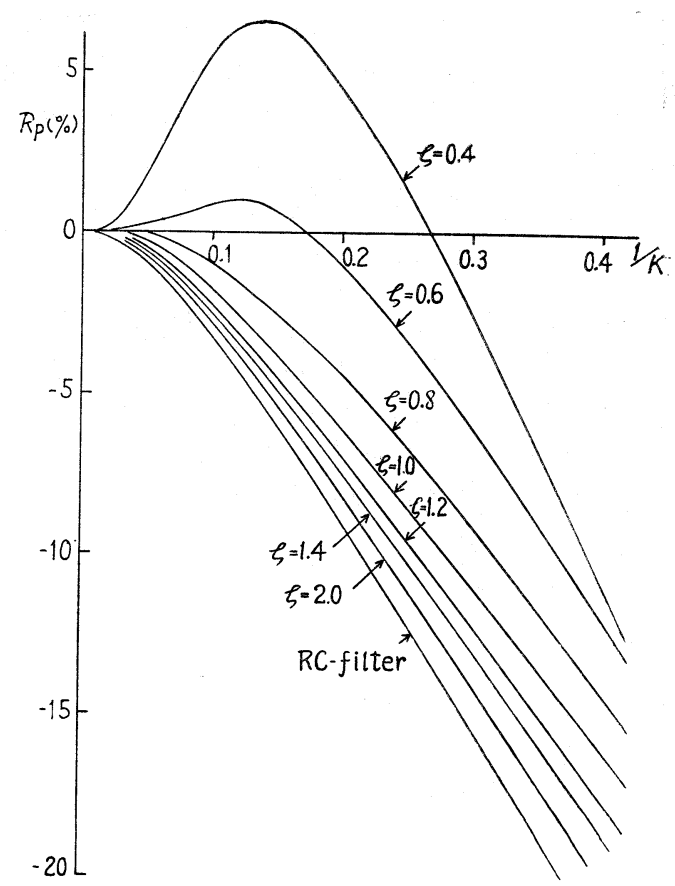

Fig. 7, (b ) 


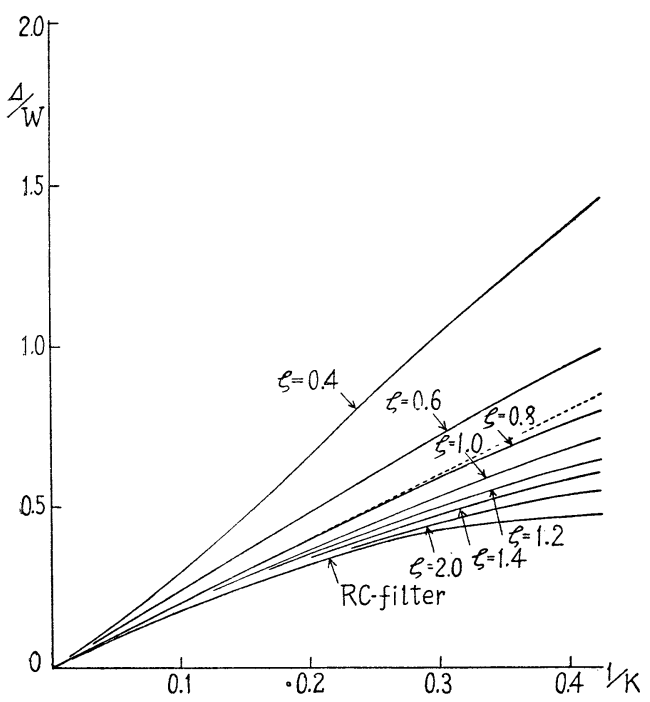

Fig. 7, (c)

Fig. 7. Tracking errors for a Lorentzian band in various system responses.

と仮定できるとき，もしピーク值の誤差の許容限度が $1.5 \%$ であれば減衰係数が 0.6 の二次系がより優れてい ることが Fig. 7 の結果から明らかである.

走查歪み交小さくするためには, 系の周波数特性が出 来るだけ高い周波数まで平坦なものが望ましいことは当 然予想される. そこで以下それぞれの系の周波数特性に ついて検討を試みる.Fig. 8 は各種の系の周波数特性 を等価雑音帯域幅を等しくして比較するために, 角周波 数 $\omega$ 等価雑音带域幅 $\Delta f$ で規格化して Bode 線図で 表わしたものである。ただし，振幅京よび位相特性は，

$$
G(j \omega)=|G(j \omega)| e^{j \angle G(j \omega)}
$$

の関係から得られる.これらの結果から, 減衰係数が 0.8 の二次系の振幅特性が他の系のそれよりもより広い 範囲で平坦であり，また位相特性は $-\omega / 4 \Delta f$ に近い ことが認められる. 停留位相の原理 ${ }^{8)}$ ととづき, 線形 系它通過したときの信号の遅れ $\Delta t$ 注

$$
\Delta t=-\frac{d}{d \omega}\{\angle G(j \omega)\}
$$

であるから

$$
\angle G(j \omega)=-\omega / 4 \Delta f
$$

であれば

$$
\Delta t=1 / 4 \Delta f
$$

8) S. Goldman: "Frequency analysis, modulation and noise", McGraw-Hill Book Company, Inc., N.Y. 1948.
宪 第 17 巻 第 4 号

となり, line shift $\Delta$ は

$$
\Delta=V t=\frac{V}{4 \Delta f}
$$

となる・したがつて筆者らの評価法では

$$
\frac{\Delta}{W}=\frac{V}{4 W \Delta f}=\frac{2}{K}
$$

となり，この比例関係は Fig. 6 (c), 7 (c) に点線で画い てあるが，Fig. 8 の位相特性からも最適系の line shift が広い範囲でこれら直線で近似できることがわかる。

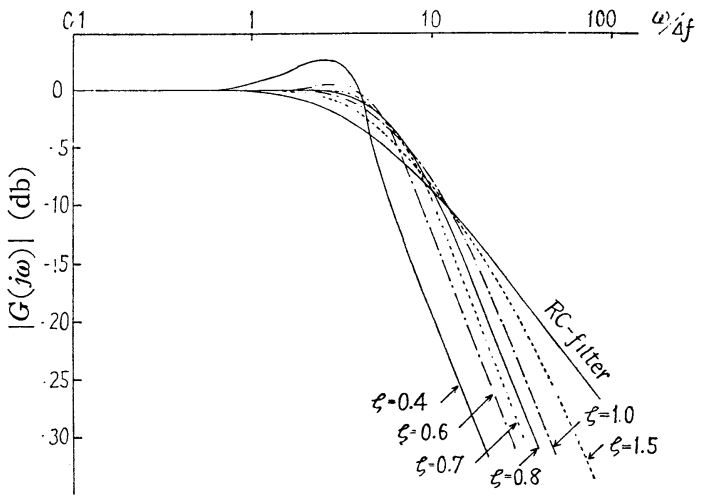

(a)

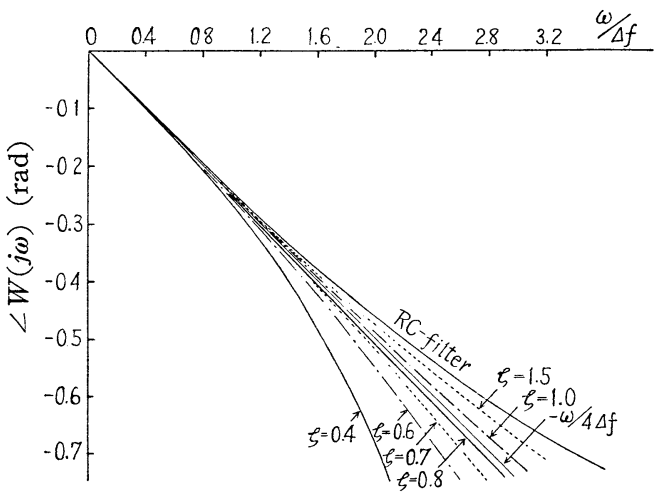

(b)

Fig. 8. Comparison of the frequency responses for second order systems under the same noise equivalent band width. (a) amplitude versus frequency, (b) phase angle versus frequency.

\section{5. 走査歪みの実例}

走查歪みの解析結果を実用的見地から検討するため， 市販の装置を用いて走査歪久を実測してみる必要があ る. この場合最も問題となるの泣装の伝達関数決定法 だする。 
Stewart ${ }^{6)}$ は試料光束を変調して 直接装置 の周波数特性を決定しているが，実用上繁雑 な手続を要するから，筆者らはより簡単に実 施出来る系のインデイシャル応答を利用する 方法を用いた。一次系の時定数はその系のイ ンデイシャル応答が定常值の約 $63.2 \%$ に達 する時間であることを利用して測定されるこ とが多いが，筆者らはこの手法を二次系にも 適用してみた．任意の二次系のインデイシャ ル応答で定常值の $50 \%$ 㐨よび $80 \%$ 亿達す る時間をとれぞれ $t_{50}, t_{80}$ とすれば，これら の比 $t_{80} / t_{50}$ : は減衰俰数の関数として Fig. 9 (b) に示さ机る関係にある. 同様に $t_{80}$ に かわり，他の值たとえば定常値の $90 \%$ に達 する時間を考光ても同様の曲線が画かれる。 また $t_{50}$ と固有周期 $T$ の比 $t_{50} / T$, あるい性 $t_{80} / T$ なぞも同様に減衰係数の関数として

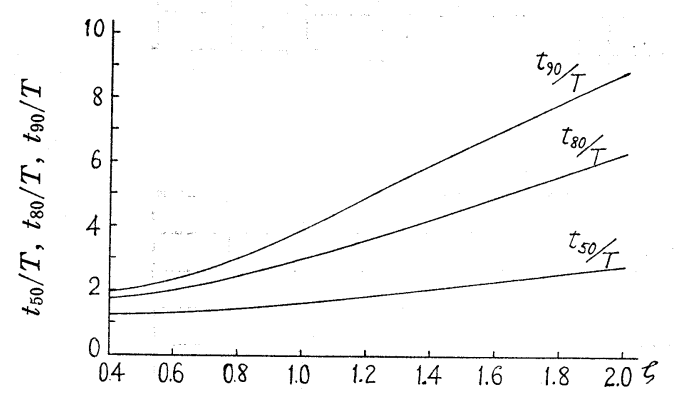

(a)

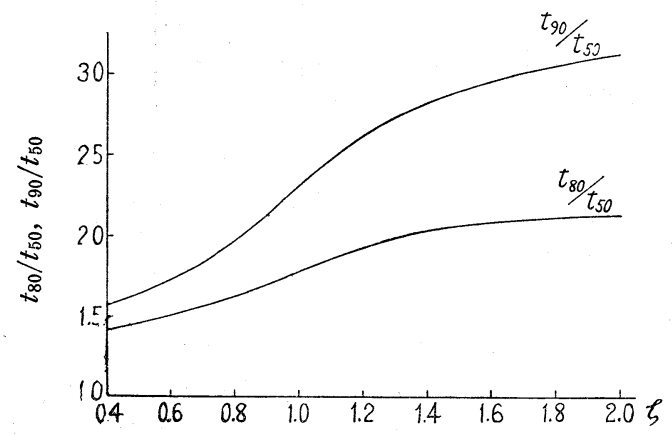

(b)

Fig. 9. Diagrams for determining $\zeta$ and $T$ of second order system from the indicial response measurements. (a) plots of $t_{50} / T$, $t_{80} / T$ and $t_{50} / T$ as a function of damping coefficient $\zeta$. (b) plots of $t_{80} / t_{50}$ and $t_{90} / t_{50}$ as a function of $\zeta$.

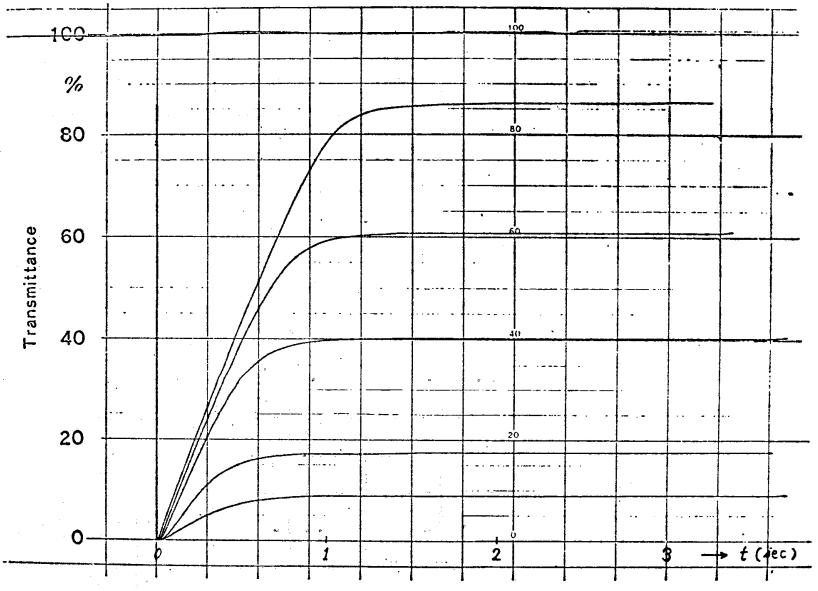

Fig. 10. Example of indicial responses of a commercial double-beam infrared spectrophotometer for various sample beam intensities.

Fig. 9 (a) に示されるような関係にある.したがつて， 実際の自記分光測光装置の伝達関数它決定するときに は，まず試料光束のシャッタ定瞬間的に開きそのときの ペンの応答を一定時間送りの状態で記録しインディシャ 儿応答とする。この結果から直ちに Fig. 9 (b) の関係 を用いて減衰係数が定められ，次に Fig. 9 (a) によつ て固有周期が定められることになる。この場合これら定 数の測定精度は時間 $t_{50}, t_{80}$ などの精度に依存するの で, 記録紙の送り速度を出来るだけ一定から高速にする ことが望をしい。

Fig. 10 は市販の自記分光測光装置（日立 225 型）の インデイシャル応答の一例で, 前述の方法で記録したも のである.この際注意すべきことは害際の機器では大信 号に対して多少なりとも必ず増幅器あるいはサーボモー タの飽和現象が起こり，いわば非線形動作をすることに なつてこれまでの議論の適用が困難となることである.

Fig. 10 に执いてもこの傾向が顕著隹められるからイ ンデイシャル応答の測定に際しては, 装置の動作が充分 に線形と考えられる範囲にあるように光束を適当に減衰 させなければならない。反面実測值には雑音が重畳して 和り，これが定数決定時の誤差要因の一つとなるから， 線形々考光和らる範围で出来るだけ大きなインデイシャ 儿応答学採用すべきこと浭めて述べるまでもない。

Fig. 11 (a) は (b) に示すインデイシャル忘答をもり 様に実際の分光光度計它設定した場合に現わ和る走査歪 みの実測例であり，対象は Benzene の $1036 \mathrm{~cm}^{-1}$ の 吸收带である。 


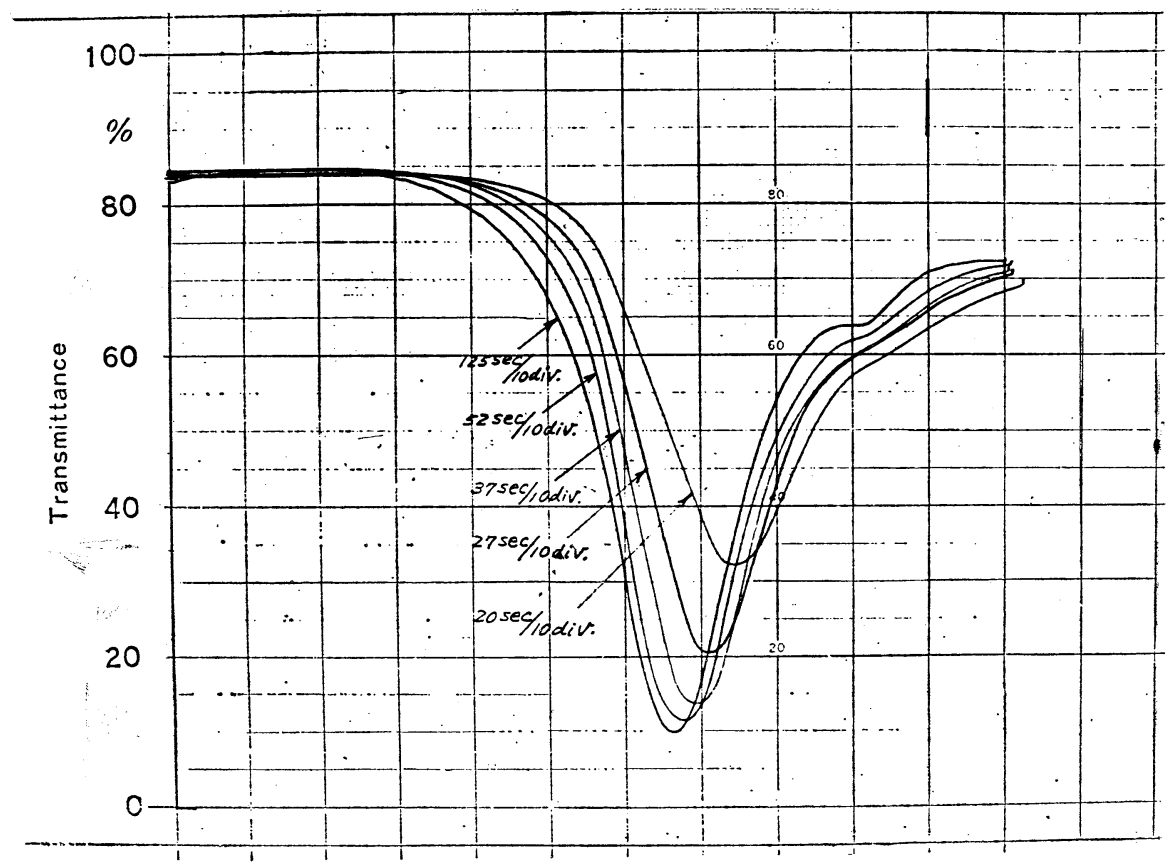

(a)

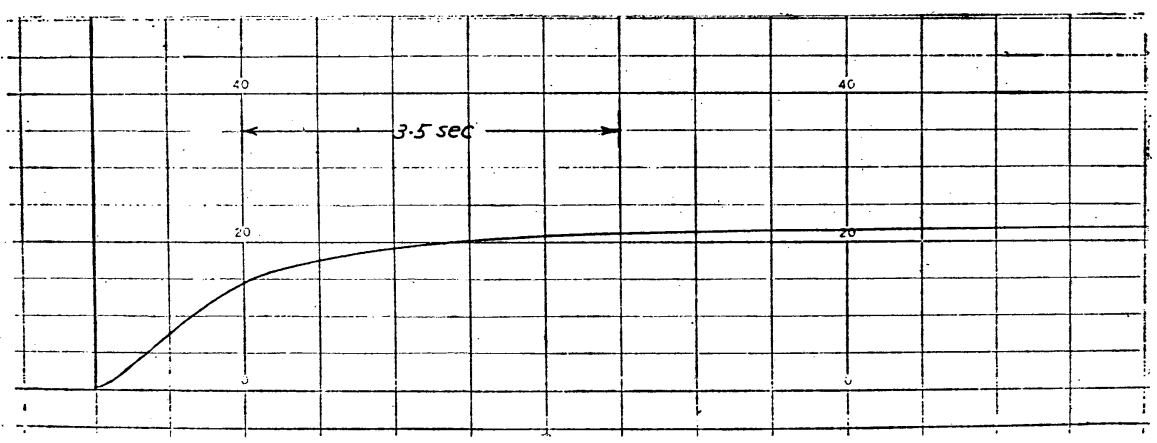

(b)

Fig. 11. Typical band distortion (a) caused by a system of which indicial response is shown in (b). (Benzene band at $1036 \mathrm{~cm}^{-1}$ )

Fig. 12 は Fig. 11 に示したようなデータを各種の 動作条件に対して集積し, 上記の方法で装置の伝達関数 を測定した後, 吸收带をL Lorentz 形として走査歪みの 解析を行なつた結果の一例である. 試料は同じくベンゼ ンの $1036 \mathrm{~cm}^{-1}$ の吸収スペクトルである. Fig. 13 は このスペクトルで走查歪みが充分に無視できると考光ら れる状態で記録したものであり，別にピーク值および半 值幅を記録スペクトルのそ㣗に等しくした Gauss 形お よび Lorentz 形波形も合せて画いてある. 以上の結果
から，このスペクトルが Lorentz 形波形に近似出来る ことは明らかである. Fig. 12 の実線は Fig. 7 の曲線 の必要部分のみを描いたものである. 走查歪みの実測值 がこの曲線に一致しないのは, Fig. 13 に示されるごと く実際のスペクトルが真の Lorentz 形波形でないとと にも原因しているが，むしろ実測される記録スペクトル に含ま机る雑音による走査歪みの測定誤差ならびに波長 走査速度が必ずしも一定でない事などの影響が大きいも のと考光られる、しかしアナログシミュレーションによ 
り求めた走查歪みの值と実測值とは実用上充分な範囲で 一致して拈り，シミュレーションにより兑られた結果が 実際の分光測光時における走査歪みの解析また注補正に そのまま適用しらることが明らかとなつた。

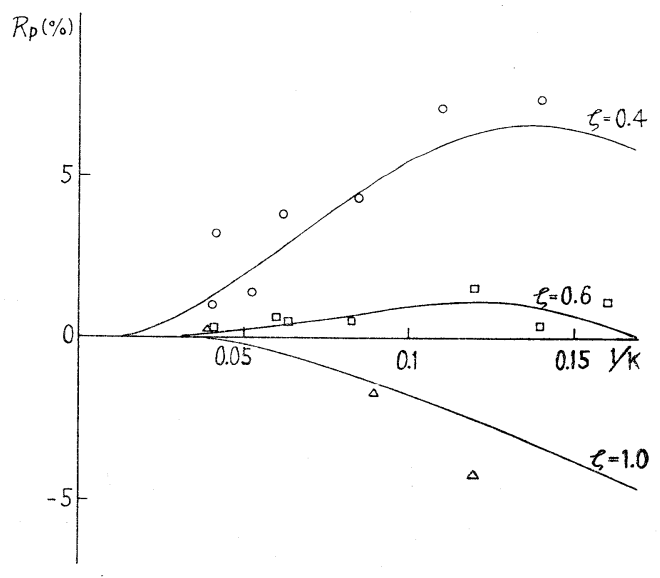

(a)

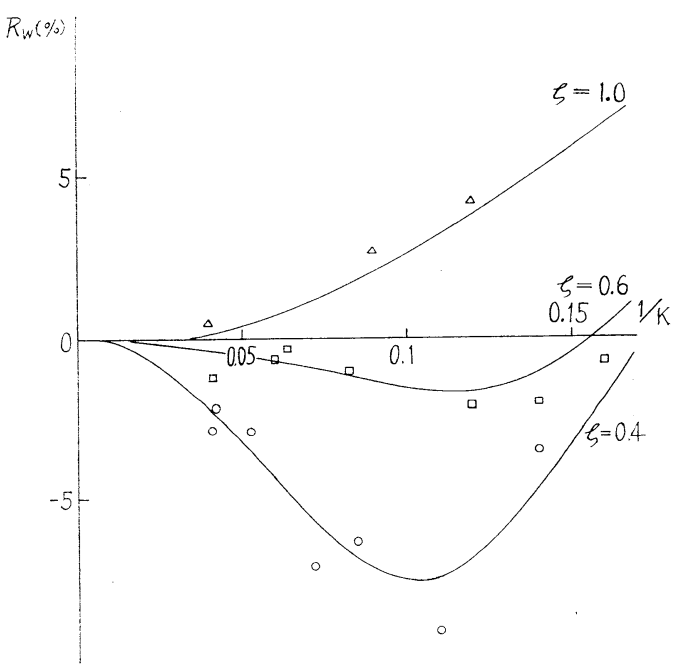

(b)

Fig. 12. Experimental peak height errors (a) and half-width errors (b) of the benzene band measured with a commercial instrument. The solid lines are derived with the simulation technique for a Lorentzian band.

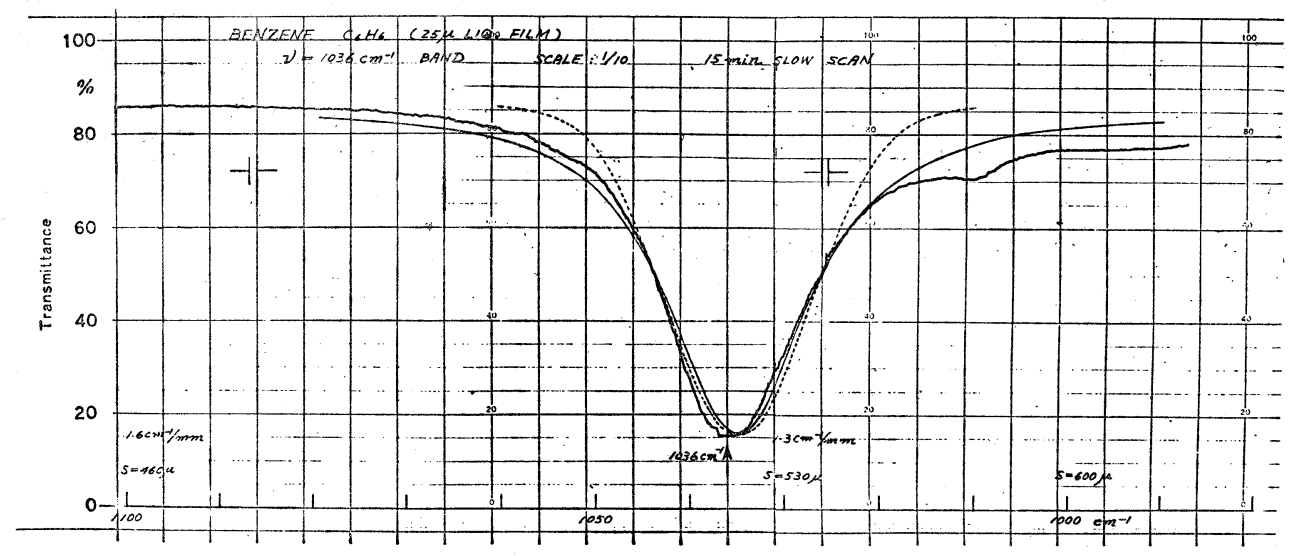

Fig. 13. The benzene band taken under the extremely slow scanning rate. Dotted and solid lines respectively shows the calculated Gaussian and Lorentzian band profiles.

\section{6. 結言}

自記分光測光系の伝達関数が実用される測定条件の下 では一次系あるいは二次系で近似されることを導き，こ れらの系による Gauss 形および Lorentz 形スペクト ルの走查歪みをナナログシミュレーションの手法によつ て解析した. 走査歪夕注真のスペクトルに対する記録ス ペクトルのピーク值および半值幅の誤差ならびに line shift で評酒安行なつた. 以上の結果から自記分光測光
における最適系は減衰系数が 0.8 日次系であることが 明らかであるが，乙れは周波数特性を検討することによ つても確認される. 単光束㨁接方式の伝達関数は一般に は減衰係数が 1 以上の系となり, 最適系は複光束光学的 零位方式で実現されることになる。したがつて装置の使 用上の特長は別として, 測光方式としては, 複光束光学 的零位方式が種々の点で優れていることが良く知られて いるが，上記のごとく最適系が実現される点に出いて もこの方式が有利であることがいえる。しかしながら 
Fig. 2 のブロック図からも明らかなように，この系の

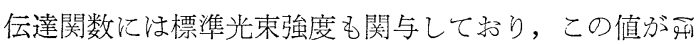
ぼ一定と考えられる範囲に㧍いての夕以上の事がいえる のであつて，系の特性を一定に保つためにはスリット幅 を制御したりあるいは AGCを用いるなどの必要性があ ることにもなる。ささらに装置によつては speed suppression が用いられることが多いが，この場合はもる ろえ筆者らの解析の対象外である.

最後に実用されている自記分光測光装置を用いて吸収 スペクトルの走査歪みを実測し，筆者らの解析結果が実 用上の見地から充分に妥当なととを確認した。今日市販
されている自記分光測光装置で高精度のものほざ使用者 の設定すべき動作諸元が多くなり，これらの選択はほと えど使用者の経験にゆだねられているのが実状である が，この解析結果はこの際の選択基準となり得るものと 考えられる.

終わりに望み本研究を行なうに当たり, 終始御指導を 賜わつた大阪大学工学部応用物理学教室藤田茂教授, な らびに赤外分光光度計の使用に当たり種々御便宜を計つ ていただいた日立那河工場の方々にこの紙面をかりて厚 く御礼を申し上げる次第である. 